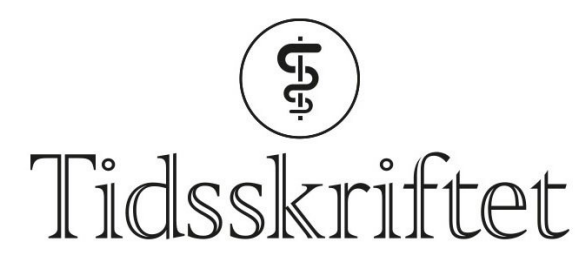

DEN NORSKE LEGEFORENING

\title{
Stillhet
}

ESSAY

\section{ØYSTEIN FIGENSCHOU}

E-post: figofant@gmail.com

Øystein Figenschou er medisinstudent på 12. semester ved Universitetet i Oslo, med en

fordypningsoppgave om bruk av stillhet i den kliniske konsultasjonen. Han har master i komposisjon fra Norges musikkhøgskole.

Forfatteren har fylt ut ICMJE-skjemaet og oppgir ingen interessekonflikter.

\section{HARALD JODALEN}

Harald Jodalen er spesialist i allmennmedisin og førsteamanuensis ved Avdeling for allmennmedisin, Universitetet i Oslo.

Forfatteren har fylt ut ICMJE-skjemaet og oppgir ingen interessekonflikter.

Kommunikasjon er et sentralt verktøy i lege-pasient-forholdet. Bruk av det monumentale virkemidlet stillhet er derimot lite nevnt. Hvorfor det? Stillhet er ikke ingenting. Stillhet har en viktig rolle i konsultasjonen og bør vies større oppmerksomhet. 


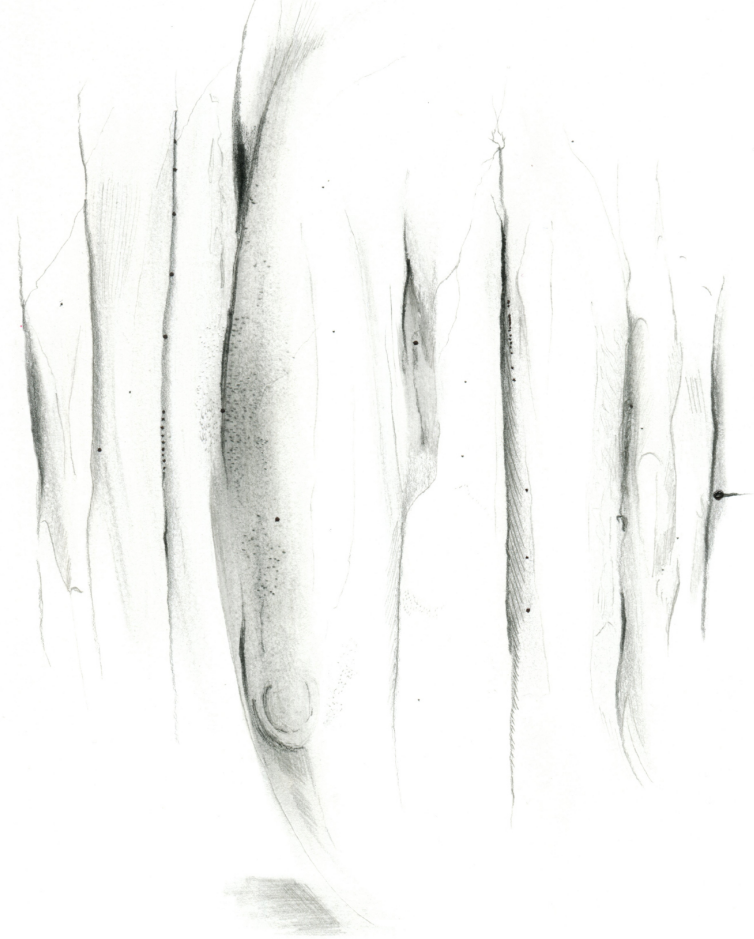

Illustrasjon: Øystein Figenschou

«Tilfør en ny dimensjon til kommunikasjonen, og berik møtet mellom lege og pasient» (1).

Å legge til rette for stillhet er viktig. På den måten vil man kunne utforske flere aspekter ved konsultasjonssamtalen og bedre kommunikasjonsferdighetene betraktelig. Bevisst bruk av stillhet vil kunne føre til bedre etterlevelse hos pasienter, være tidsbesparende og motvirke misforståelser både hos pasient og lege.

Stillhet har blitt en begrenset ressurs. Støyen øker og tiden minker. Stillheten er håndfast og konkret, og brukt rett er den et meget kraftig verktøy. For å kunne bruke stillhet må man anerkjenne at den eksisterer og er meningsbærende. Deretter må man være bevisst på prosessene den igangsetter. Stillhet i dialog kan brukes både til å bryte ned og til å bygge opp. Fordi stillhet er et så sterkt virkemiddel, kreves det musikalitet og empati i utførelsen.

Å etablere et godt lege-pasient-forhold kan gå fort eller skje gradvis. Enten man er det bevisst eller ikke, foreligger det alltid et subjekt - legen - og et objekt - pasienten (2, kap. 9). Det er denne rollefordelingen som ligger til grunn for den kliniske samtalen. Magien i klinisk kommunikasjon skapes i møtet med pasienten. Å gi rom til pasienten med stillhet er å anerkjenne pasienten.

\section{Tidskrevende eller tidsbesparende?}

Stillhet er, som alle lydfenomener, noe som utspiller seg i tid. Det er lett å tenke seg at å bruke stillhet er tidkrevende, men det er mer fornuftig å tenke på denne tiden som en investering, heller enn en utgift man aldri får igjen. På sikt er det å bruke stillhet tidsbesparende. I Hunskårs lærebok i allmennmedisin fremheves en studie fra 1984 som viser at legen i gjennomsnitt avbryter pasienten etter 18 sekunder (3). Ved å la pasienten få snakke fritt kan man komme raskere til sakens kjerne. Avbrytelser i et fors $\emptyset \mathrm{k}$ på å være effektive kan fort virke mot sin hensikt. Stillhet er det ultimate åpne spørsmålet.

Å gi rom til pasienten med stillhet er å anerkjenne pasienten 
Hvor lenge en stillhet varer, har mye å si for meningsinnholdet. En veldig kort pause kan understreke et poeng, en litt lengre pause fasiliterer dialogen, mens de lengre pausene gir pusterom etter mye informasjon. Jo lenger enn pause varer, jo mer meningsbærende blir den, og jo mer tyngde får den. Hvor lang skal stillheten være? Det finnes ingen eksakt fasit, men det kreves fingerspitzgefühl og god timing. Allerede etter o,2 sekunder er stillhet signifikant som tegn til at det er den andres tur til å snakke $(4,5)$. Retorisk stillhet oppnås etter 1-2 sekunder, og en stillhet på 4-5 sekunder oppleves gjerne som en avventende gest eller tenkepause. En 10-15 sekunders lang stillhet er betydningsfull som en egen bestanddel i samtalen, på linje med et utsagn og med betydning etter hvordan grunnen er preparert og hva kroppsspråket sier. En slik stillhet kan være både konfronterende, kalibrerende og bearbeidende, og alle disse typer stillhet bør gis plass som selvstendig meningsbærende elementer.

Vi sleper alltid på en «hale» i vår auditive persepsjon. Vi både lytter, prosesserer og planlegger samtidig. Dette er sentralt i oppfattelsen av setninger. Dersom vi ikke hadde hatt denne evnen, ville vi bare hørt enkeltord og mistet all sammenheng med de andre ordene. Ikke uventet kreves det å planlegge responser under prat mer hjerneprosessering enn hvis det er stille (6).

Det er vanlig å reagere med usikkerhet på stillhet. Stillhet kan bety fare. I en studie der man så på hjerneaktivitet mens det var stille, både i samtale og etter at en musikalsk akkord var spilt, fant man at temporal korteks ble aktivert av stillhet (7). Dette indikerer at opplevelsen av stillhet er mer enn en passiv prosess. Stillhet skaper forventning. Ved å la en oppmerksom stillhet råde gir vi rom for at pasienten kan velge retningen. Det gir også legen tid til å tenke mer. Avhengig av kroppsspråk vil stillhet også kunne fungere som en naturlig avslutning. Stillheten har da en avklarende effekt (8).

\section{Stillhet i klinisk kommunikasjon}

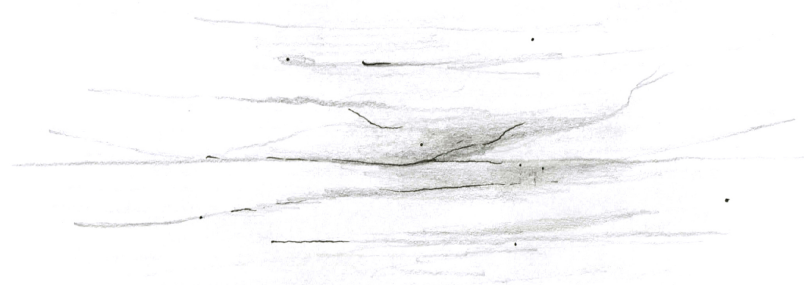

Illustrasjon: Øystein Figenschou

Stillheten er dynamisk ved at den kan vokse og krympe. Den kan være makroskopisk eller mikroskopisk, ubetydelig eller monumental. Stillhet oppstår og stillhet skapes. Dette er et grunnleggende forhold ved stillheten. Ofte oppleves den oppståtte stillheten som et problem mer enn som en mulighet. Som verktøy i den kliniske samtalen har den et betydelig potensial.

Ved å la pasienten få snakke fritt kan man komme raskere til sakens kjerne

Stillhet kan være intendert og uintendert. Antakelig er det nettopp fordi stillhet ofte oppstår uintendert, at mange er ukomfortable i situasjoner der stillheten ruver. Når det skjer ting man ikke har kontroll over, er det forståelig at man kan reagere med forvirring og usikkerhet.

Fornuftig bruk av stillhet forutsetter at legen har gode intensjoner. Legen styrer, gir rom og fokus. Det er særlig den intenderte stillheten som er av interesse, fordi det fordrer at legen aktivt legger til rette for, eller selv skaper, denne stillheten. Den intenderte stillheten må også aktivt vedlikeholdes.

Opplevelsen av stillhet er mer enn en passiv prosess. Stillhet skaper forventning

Den uintenderte stillheten krever tolkning og kontekstuell forståelse. Denne 
tolkningssituasjonen utdypes ikke nærmere her, da vi velger å vektlegge den bevisste, intenderte bruken av stillhet. Vi har begrenset oss til tre kraftige varianter av intendert stillhet, som krever legens bevissthet og tilrettelegging: kalibrerende, konfronterende og bearbeidende stillhet (1) (tabell 1). I tillegg kan man kategorisere stillhet etter dens effekt (ramme 1) (1).

\section{Tabell 1}

Matrise for å illustrere hvordan intendert og uintendert bruk av stillhet kan fungere som verktøy i konsultasjonen både ut fra en ressursorientert og en problemorientert forståelse av situasjonen.

\begin{tabular}{|llc|}
\hline & Ressursorientert forståelse & Problemorientert forståelse \\
\hline Intendert/aktiv bruk & $\begin{array}{l}\text { Kalibrerende stillhet } \\
\text { Bearbeidende stillhet }\end{array}$ & Konfronterende stillhet \\
\hline Uintendert/passiv bruk & $\begin{array}{l}\text { Kan bli en ressurs ved smidig } \\
\text { tolkning og kontekstuell } \\
\text { forståelse }\end{array}$ & Ubehagelig stillhet \\
\hline
\end{tabular}

\section{Ramme 1 Mulige effekter ved stillhet}

Nedbrytende stillhet

Stillheter med potensielt skadelige effekter på lege-pasient-forholdet.

Uvøren bruk, manglende forståelse for situasjonen eller feil kroppsspråk vil kunne bidra negativt.

Informasjonsinnhentende og -formidlende stillhet

Stillheter som bidrar til innhenting og formidling av informasjon.

Stillhet er fasiliterende og bidrar til bedre informasjonsprosessering $(1,2)$.

Emosjonsbehandlende stillhet

Stillheter i forbindelse med emosjonelle situasjoner.

Stillhet gjør at legen kan møte pasientens emosjonelle situasjon uten selv å tre inn i den.

Stillhet som virkemiddel

Bruk av stillhet som instrument for å styre ulike aspekter ved konsultasjonssamtalen.

Stillhet kan aksentuere, lede, fasilitere og avslutte.

\section{KALIBRERENDE STILLHET}

Hver gang vi møter en pasient omstiller og tilpasser vi oss. Kalibrerende stillhet er bevisst stillhet som har til hensikt å la oss komme på bølgelengde med pasienten i den aktuelle situasjonen. Tiden fra man hilser til man er klar til å snakke, er et slikt eksempel. En liten kalibrering i begynnelsen kan være positivt for både tillit og profesjonalitet. Underveis i en konsultasjon kan man skli fra hverandre, eller det dukker opp temaer og problemstillinger som krever omstilling. En kalibrerende stillhet kan også ha til hensikt å avgjøre hvor problemet ligger.

\section{KONFRONTERENDE STILLHET}

En konfronterende stillhet er et kraftig virkemiddel. Den er utadrettet og aggressiv. Hensikten er åpenbart en konfrontasjon, for eksempel et ønske om en oppklaring eller tydeliggjøring av en problemstilling. Ikke helt sjelden er det pasienten som tyr til denne. Konfrontasjonen kan være formet som et spørsmål, med kroppsspråk eller med et tonefall som er tydelig på at man krever et svar. Også legen kan benytte konfronterende stillhet. Et godt eksempel er situasjoner der alkoholmisbruk og bilkjøring tas opp. Her kreves 
varsomhet. Solid tillitt i relasjonen er ofte nødvendig for å kunne bruke konfronterende stillhet uten at det oppstår konflikt.

\section{BEARBEIDENDE STILLHET}

Skal man si noe viktig, kan man ikke prate hele tiden. Etter å ha gitt eller mottatt informasjon som medfører større konsekvenser, er det kanskje spesielt viktig med stillhet. Slik stillheten bør som regel vare lenger enn man tror, så gi litt ekstra tid. Jo større konsekvens, desto lenger bør stillheten vare, rett og slett fordi prosesseringen i slike tilfeller tar lengre tid. Dessuten setter konsekvenstunge beskjeder i gang tankerekker som kan være tidkrevende.

\section{Diskusjon}

Hva man kaller en stillhet, spiller ingen rolle. Den eksisterer og både kan og bør brukes aktivt. Den praktiske bruken av stillhet krever evne til å lytte. Effektiv kommunikasjon fordrer en del erfaring og ikke minst musikalitet i form av timing og tonefall. I den kliniske situasjonen kan dette oversettes til hvordan noe sies, og når noe sies, jamfør retorikkens patos og kairos. Ved bruk av stillhet er det kanskje når som er viktigst. For å komme unna med å bruke stillhet må den komme på rett sted til rett tid. Turtaking i samtale er et meget finslipt apparat. Selv ørsmå variasjoner i pauser eller overlapp oppfattes (4).

Skal man si noe viktig, kan man ikke prate hele tiden

Hvordan man går inn i og ut av stillheten, er ikke uten betydning. Å starte med lavt volum og snakke høyere og høyere har en dramatisk effekt. Det er veldig spenningsoppbyggende, og det som kommer etter en slik oppbygging vil kunne få stor tyngde. En stillhet vil kunne bli massiv. For å kunne bruke stillhet som virkemiddel bør man fremfor alt være bevisst på når den kan brukes og hvorfor den skal brukes.

Bruk av stillhet i pasientkommunikasjon må øves på. Stillheten er som et hvilket som helst annet kraftig verktøy: potensielt farlig ved uvøren bruk - og veldig effektiv til rett jobb. Stillhet kan virke nedbrytende på samtalen og forholdet hvis man ikke har noen klar intensjon, men med fornuftig og smakfull bruk kan man løfte forholdet og samtalen til nye høyder.

\section{LITTERATUR:}

1. Figenschou $\emptyset$ J. Multipotent stillhet - et instrument i den kliniske samtalen. Masteroppgave. Oslo: Universitetet i Oslo, 2019.

2. Jodalen H, Vetlesen AJ. Closeness. Oslo: Universitetsforlaget, 1997.

3. Hunskår S. red. Allmennmedisin. 3. utg. Oslo: Gyldendal Akademisk, 2013.

4. Fors KL. Production and perception of pauses in speech. Doktoravhandling. Gøteborg: Universitetet i Gøteborg, 2015.

5. Wilson M, Wilson TP. An oscillator model of the timing of turn-taking. Psychon Bull Rev 2005; 12: 957-68. [PubMed][CrossRef]

6. SanMiguel I, Widmann A, Bendixen A et al. Hearing silences: human auditory processing relies on preactivation of sound-specific brain activity patterns. J Neurosci 2013; 33: 8633-9. [PubMed][CrossRef]

7. Barthel M, Sauppe S. Speech planning at turn transitions in dialog is associated with increased processing load. Cogn Sci (Hauppauge) 2019; 43: e12768. [PubMed][CrossRef]

8. Tindall RH, Robinson FP. The use of silence as a technique in counseling. J Clin Psychol 1947; 3 : 136-41. [PubMed][CrossRef] 
Publisert: 7. januar 2021. Tidsskr Nor Legeforen. DOI: 10.4045/tidsskr.20.0585 (C) Tidsskrift for Den norske legeforening 2020. Lastet ned fra tidsskriftet.no 